\title{
Media and Religion: Study of Anti-Shi'a Propaganda in Yogyakarta
}

\author{
Anang Masduki ${ }^{1,2)}$ Panqiang Niu ${ }^{3, a)}$ Agus Triyono ${ }^{4)}$ \\ ${ }^{1}$ Communication Department, Universitas Ahmad Dahlan, Yogyakarta, Indonesia \\ ${ }^{2}$ School of Journalism and Communication, Shanghai University, China \\ ${ }^{3}$ School of Journalism and Communication, Shanghai University, China \\ a) author correspondence : panqiangniu@163.com \\ ${ }^{4}$ Communication Department, Universitas Muhammadiyah Surakarta, Indonesia \\ DOI: https://doi.org/10.18196/jkm.131048
}

\section{Article Info}

Article history: Received 24 Feb 2021 Revised 19 Apr 2021 Accepted 25 May 2021

\section{ABSTRACT}

Some time ago, a rift arose between Sunnis and Shiites in Sampang, Madura. Then, banners spread across Yogyakarta stating that the Shia were heretical. On the internet, many websites sprang up claiming that anyone that justifies Shia is heretical. These were a form of propaganda, campaigning, or "proselytizing" that another group is deviant and infidel. This research tried to analyze the propaganda process in the media by radical groups against Shiite groups in Yogyakarta and to find out the techniques and tools used in it so that all parties could anticipate and map the potential conflicts. The research was conducted in Yogyakarta with a qualitative research type. Data collection was carried out by document review. The results showed that, first, propaganda provided a stimulus to the public to seek knowledge and information about the Shi'a group -and mainly conveyed a negative view of the Shi'a group. Second, this research found that the mechanism carried out was by providing information to the public by placing the media in strategic places. Third, the research identified that the propaganda theory used is Name-Calling, Glittering Generality, and Transfer, while the media used were billboards, banners, leaflets, and brochures.

Keywords: Media; propaganda; shia; Yogyakarta

\section{ABSTRAK}

Beberapa waktu lalu, terjadi keretakan antara Sunni dan Syiah di Sampang, Madura. Kemudian marak bertebaran spanduk di Yogyakarta yang menyatakan jika Syiah adalah sesat. Selanjutnya, di internet, banyak bermunculan situs-situs internet yang menyatakan sama sampai ke tingkat individu, dimana status media sosial yang membenarkan Syi'ah adalah sesat. Inilah salah satu bentuk Propaganda, berkampanye, atau "berdakwah" jika kelompok atau kelompok lain sesat dan kafir. Penelitian ini mencoba menganalisis proses propaganda yang dilakukan di media oleh kelompok radikal terhadap kelompok syiah di provinsi Yogyakarta dan mengetahui teknik dan alat yang digunakan dalam propaganda. Hal ini dilakukan agar semua pihak dapat mengantisipasi dan memetakan potensi konflik yang akan terjadi seperti yang diharapkan sejak dini. Penelitian dilakukan di Yogyakarta dengan jenis penelitian kualitatif. Pengumplan data dilakukan dengan telaah dokumen. Hasil penelitian, pertama, propaganda memberikan stimulus kepada masyarakat agar mau mencari pengetahuan dan informasi tentang kelompok Syi'ah. Propaganda tersebut memberikan pandangan negatif kepada masyarakat tentang kelompok Syi'ah. Kedua, Mekanisme kerja propaganda yang dilakukan media adalah memberikan informasi kepada masyarakat umum dengan dipasangnya media tersebut di tempat-tempat strategis. Ketiga, teori propaganda yang digunakan adalah NameCalling, Glittering Generality, Transfer. Sedangkan media yang digunakan adalah Baliho, Spanduk, Leaflet, Brosur.

Keywords: Media; propaganda; siah; Yogyakarta 


\section{INTRODUCTION}

Sunni and Shi'a issues have indeed become global issues. According to Azra (2015a), the feud has resulted in a proxy war or open war with the third-person hands because it is not merely ideological differences but has political matters. It is about Saudi Arabia, the Sunni Wahhabi, who faced and struggled for influence with the Shi'a Iranian state (Azra, 2015a). The development of the regional geopolitical struggle between Saudi and Iran extends beyond the Middle East region, entering predominantly Muslim countries, including Indonesia. It is possible due to the abundant flushing of funds from the two countries in the name of religious assistance. The flow of aid implied the influx of Sunni and Shi'a political movements so that conflicting propaganda emerged (Azra, 2015b).

The main issue of Sunni and Shi'a originates from political differences. Shi'a believes in the existence of Imamiah Itsna' Asyariah, which means the Twelve Imams. They think that only imams have the right to lead Muslims, and they believe there are twelve of them (Hitti, 2008, p. 56). In the subsequent development, the Shi'a politically thought that only the children and descendants of the Prophet Muhammad through Ali had the right to lead the Muslim community. It has implications for ideological problems (Subhani, 2012, p. 144). In Indonesia, Shi'a followers entered a few centuries ago, but the Old and New Order period's political constellation did not provide room for them to develop. Shi'a in Indonesia gained momentum during reform. In 2001 located in Jakarta, an organization called IJABI, which stands for the Indonesian Association of Jama'ah Ahlul Bait, under the guidance of Jalaluddin Rahmat, was established (An-nahidl, 2014, pp. 114-132).

The radical movements of religious groups that are not in line with Shi'a adherents in Indonesia emerged several years ago. What has attracted enough attention is the expulsion of the Shi'a group by Sunnis in Sampang, Madura (Viva.co.id, 2011). It resulted in burning and even violent fighting, so that the Shi'a group had to be evacuated and live in the shelter. Unfortunately, the two groups are still brothers, but one has to be expelled from the hometown where they were born (Tempo.com, 2012). Even though Indonesia is a democracy and has complete legal instruments, intolerant groups still exist. However, compared with the number of religious adherents in Indonesia, the number of violent cases is relatively small.

The following is the overall data on the scores for the tolerance component in Indonesia from 2014-2017.

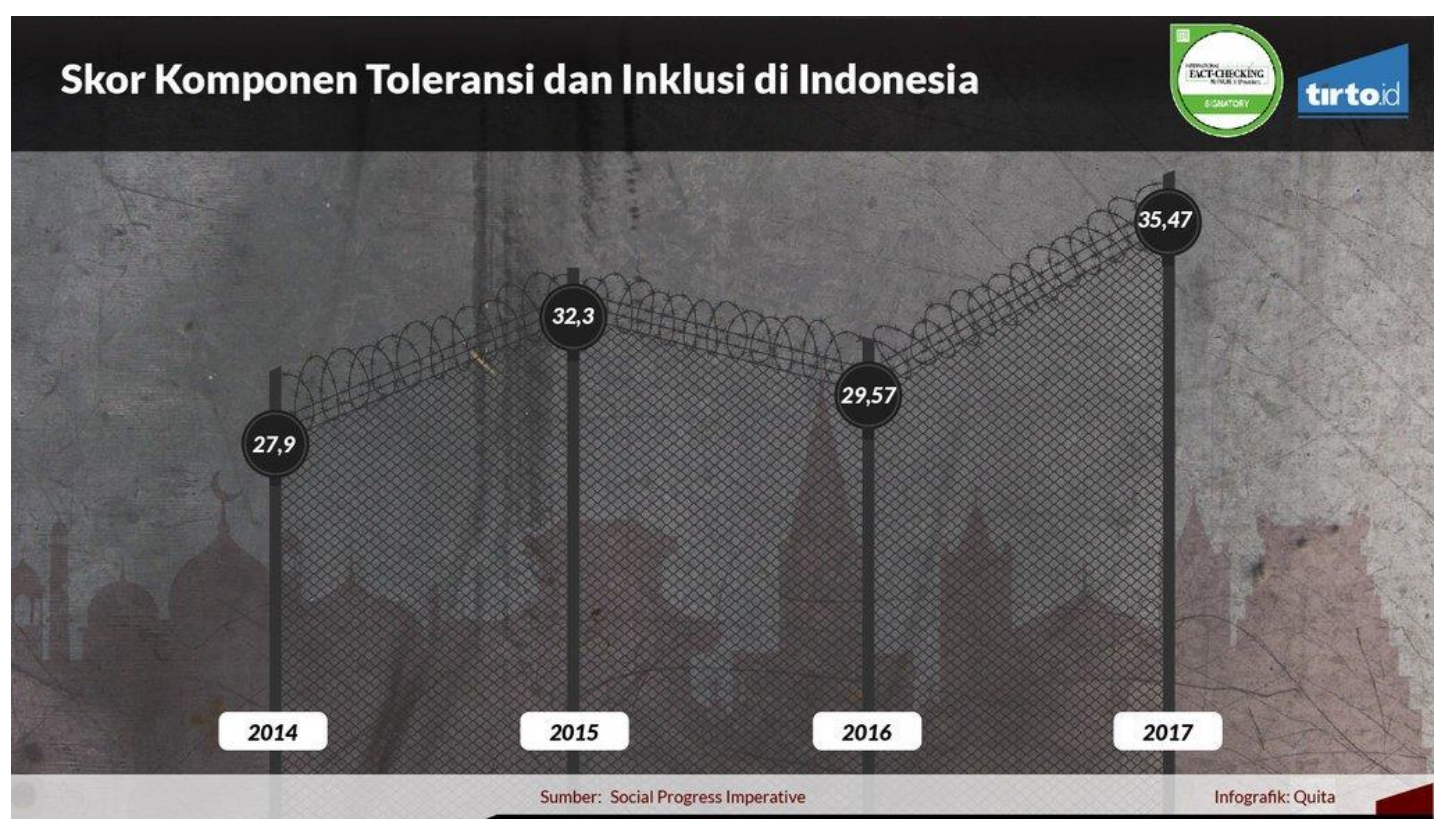

Figure 1. Tolerance score diagram in Indonesia, source (Gerintya, 2018)

Intolerance is exacerbated by other religious groups and mass organizations' propaganda to exclude other groups. Many banners, billboards, and announcements were scattered to attend a recitation containing people who were anti-Shi'a groups. The Setara Institute noted that in Indonesia, there were 270 acts of intolerance in 2016 and 155 acts of discrimination in 2017. It has also 
happened in Yogyakarta. Yogyakarta occupies the $6^{\text {th }}$ position in the lowest tolerance level. It is ironic, considering that Yogyakarta is a city of learners and has an inherent culture (Gerintya, 2018). The data for the ten cities with the lowest tolerance score in Indonesia are as follows:

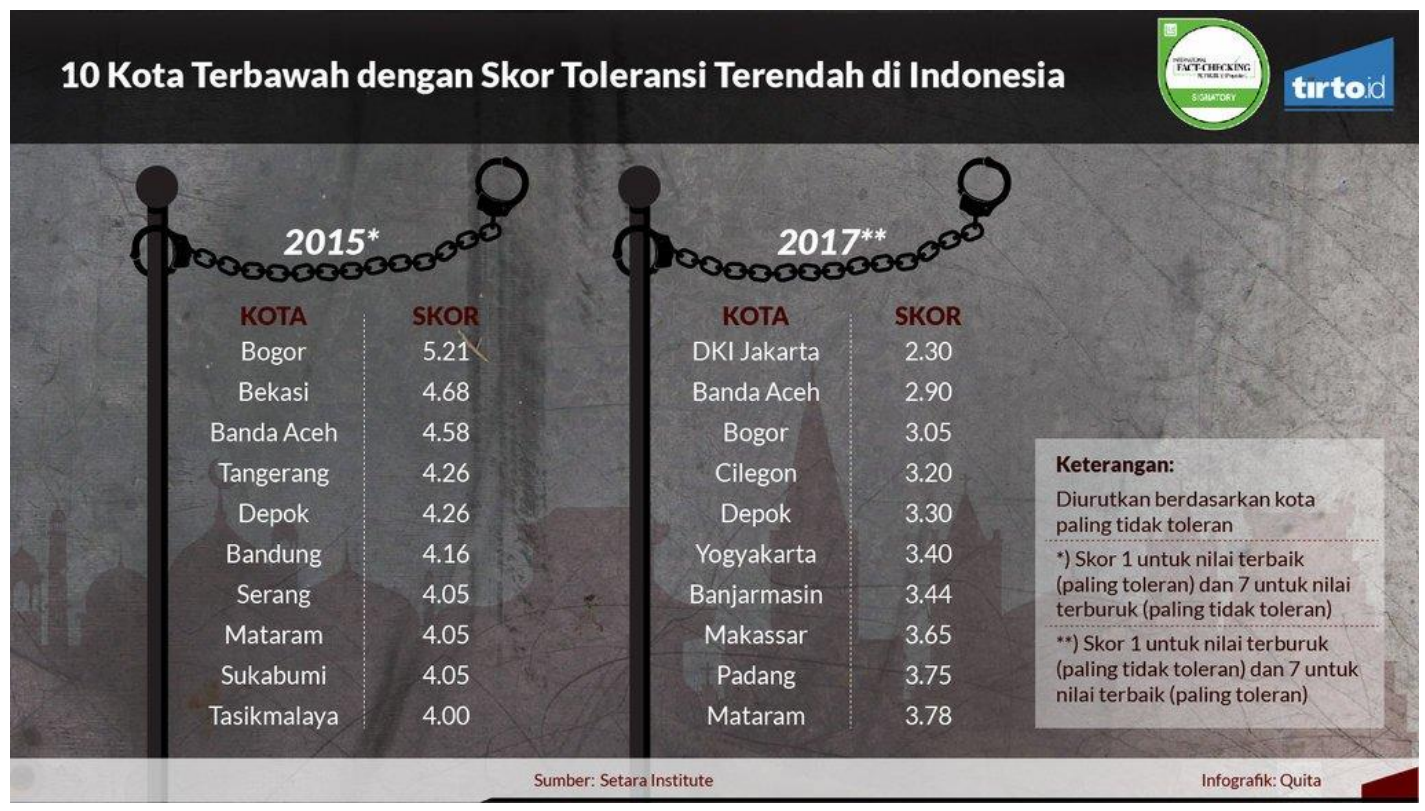

Figure 2. List of the ten lowest cities with the lowest tolerance score in Indonesia, source (Gerintya, 2018)

After the incident, it turned out that we, as Indonesians, did not take lessons. The proof is that the anti-Shi'a radicalism movement continues. Even in recent times, anti-Shi'a propaganda appears to be continuing. No exception in the province of Yogyakarta. Much media is used to justify the infidelity of the Shi'a.

According to Jowett and O'Donnel, propaganda is a deliberate and systematic attempt to shape perceptions, manipulate cognitions, and direct behavior to respond to the desired goals of the propagandist or propagandist. Mc Quail also illustrates that the term propaganda tends to be negative. McQuail explains that currently, the opposing party carries out the propaganda, whereas we provide information, evidence, and arguments (McQuail, 1994, pp. 298-299). In subsequent developments, propaganda is used in the religious and social, political, cultural, and social fields. (Nurudin, 2001, p. 9).

Propaganda which is intensively carried out face-to-face or with the media, has few or many implications for developing public perceptions. Through narrative and visualization, the media offer definitions of human life. Who are the heroes and who are the villains, which ones are good and bad for society, what is appropriate and not, which trends are relevant and which are obsolete, which values should be fought for, what actions should be taken, what solutions should be taken and abandoned (Eriyanto, 2002, p. 15).

In the media, there is an ideology (Rahmat, 2001, p. 57). By implication, language can also be used to give a particular accent to an event or action, for example, by emphasizing, sharpening, softening, glorifying, harassing, distorting, or obscuring the event or activity. In this sense, communication in the media is a battle arena for symbolic warfare with a compelling message (Junaedi, 2017, pp. 15-25). With the power to shape public opinion, the media is a tool contested by many parties to seek popularity, raise certain parties, or reduce others. Thus, it is not surprising that if there is a saying in propaganda, those who control their media will rule (Mc Nair, 1999, p. 30).

In the Indonesian context, media construction related to religious polarization, especially Islam, places Sunni as a legitimate religious ideology. However, some groups think differently. It has implications for distortion and justification for those who embrace other than Sunnis. They are considered sinful, and some even considered disbelievers/infidels. In the end, the friction between Shi'a and Sunni adherents in various regions occurred a lot and even ended in conflict (Latief, 2008, pp. 300-335). It can be a little mitigated if the news and media construction do not defend one-sided parties and provide a fair share. 
Cases of intolerance and violence against Shi'a adherents often occur, thus attracting academics' attention to research and find the root of the problem, likewise the propaganda activities in the media carried out against minorities. These studies include, first, Al Makin (2017, pp. 1-32), who conducted research investigating the persecution case against the Rhaushan Fikr office in Yogyakarta. The office was a gathering place for Shi'a groups and activities. This research used a literature study methodology. Al Makin saw that the attack was a form of intimidation that wanted to uniform religion in Indonesia. This behavior was based on the belief in differences in ideology, ritual, and politics. The two groups did not first carry out dialogue and scientific studies to find common ground and points of difference. Instead, before carrying out the attack, the professions conveyed several websites, even though the provocation did not explicitly invite attacks.

Second, research was conducted by Makhsum (2019). This research explores the anti-Shi'a propaganda carried out by the ANNAS (Anti-Shi'a National Alliance) group. The research method used was interview and literature study. This group was founded to stem the development of Shi'a groups in Indonesia. Propaganda is carried out using political movements, namely using government power. Besides that, it also uses mass media, publishing books, and scientific seminars. The propaganda carried out by the ANNAS movement is more structured and neat because it involves political and governmental forces (Makhsum, 2019, pp. 182-191).

Third, research on Sunni and Shi'a conflicts in online media was conducted by Hastuti and Maulana (2019, pp. 31-40). This method used in the research was a combination of field research and literature study. The object of this research was online media detik.com, islam.com, and arrahmah.com. The researcher also conducted interviews with several figures in Makassar. The research stated that ideology, politics, and worship are the main issues of the Sunnis and Shi'a conflict. Also, the public considered that the media affiliated with each group tended to be biased in reporting.

Fourth, Yani Tri Wijayanti conducted research entitled "Radicalism Prevention through Propaganda Awareness on Social Media" (2020, pp. 142-155). The research was conducted by conducting FGD on students in Yogyakarta. These students receive radical information and understanding from social media. As a result, student's performance had decreased after the propaganda about acts of radicalism.

The researcher's explanation above has discussed the background of the conflict between Sunni and Shi'a. It was also mentioned that anti-Shi'a propaganda was carried out with political and government approaches. Furthermore, propaganda is becoming a concern to prevent the radicalism mindset. This study seeks to complement the results of this research by looking at the techniques and processes of anti-Shi'a group propaganda carried out with the media that occurred in Yogyakarta.

From the description above, the media used by anti-Shi'a groups is certainly very influential in instilling their ideology in society. It is so strong that the press can mobilize someone to distrust other groups. These media range from newspapers, leaflets, banners, online media, social media, and news in newspapers and magazines. The question raised is how the propagation process spread even indoctrinate other people to follow certain groups. On the other hand, it is also necessary to reveal how the tools are used for propaganda or "da'wah", and how they work and perform the doctrine. The power of ideology can stick firmly in the minds of community groups in Indonesia, especially in Yogyakarta. The location of Yogyakarta was chosen because there were many media, including posters, billboards, and banners about anti-Shi'a propaganda. The researchers see that other areas are not as lively as Yogyakarta.

\section{METHOD}

This research uses a qualitative approach. This study explores and understands the meaning of cultural, social, or humanitarian problems (Creswell, 2012). This study uses a qualitative approach because it is exploratory and reveals the meaning behind the scenes (Moleong, 2017). The research strategy is carried out empirically to investigate phenomena in real life by utilizing various evidence sources to answer the "how and why" questions. There is direct contact of the researcher with the object to get a holistic and dynamic perspective, in which the researcher is the critical instrument (Salim, 2006). The media under study are billboards, banners, leaflets, brochures, pamphlets related to anti-Shi'a propaganda. There are online and offline versions of the press spread across Yogyakarta. 
The research steps are preceded by an analysis using propaganda techniques from the Propaganda Analysis Institute, which is headquartered at Yale University in the United States (Lee, 1939). There are seven propaganda techniques, detailed below.

1. Name-Calling. It is a propaganda technique by touching emotional symbols to a person, group, or country.

2. Glittering Generality. If the first technique handles with characters, this uses grandiose words to flatter. It is done to deceive the public.

3. Transfer. This technique usually uses a person's popularity to rely on as an excuse that the character is in the group if it is profitable. Still, if it is not good, then it is not considered the group. Besides that, it also uses attributes to justify it.

4. Plain folks. With this technique, the propagandist identifies an idea in which a propagandist must look like someone in general.

5. Testimonials. In this technique, propagandists usually use both adored and hated figures to promote or justify something.

6. Card stacking is to highlight the right things. Where supporting facts are gathered, including selection and falsehood, illustration or confusion, makes sense.

7. Bandwagon. This technique is done by playing with the audience's feelings by showing and heralding the success, success, and greatness of an individual, group, or organization.

After identifying the propaganda technique approach, the propaganda media content will be analyzed in more depth using content analysis. It is done to reveal the context, meaning and read communication symbols (Ahyar, 2019, pp. 100-120).

\section{RESULT AND DISCUSSION}

In Yogyakarta, there are many universities. Of course, many people come and stay. However, many people are immigrants, and most of them adhere to trans-national ideologies to influence the development of the people of Yogyakarta. Most of the community that spearheaded the anti-Shi'a propaganda process did not come from Yogyakarta. They are an educated group who have received religious education through halaqah or intensive study. It can be seen from the Tabligh Akbar (mass preaching) and the intensive studies they conducted. However, it needs to be checked, given that many banners or billboards have a provocative tone that is put up for a long time so that authorities such as the police can take action. If misconduct is found, the soldiers usually swiftly taking it down. Here, strong leadership is needed to bring orders to take action against perpetrators of intolerance (Assiddiqie, 2014).

Another view is that the causes of radicalism result from unfair political and economic policies, namely broad inequalities of welfare and differences in government systems, namely democracy that is considered secular (Anshori, Nurhasanah, \& Napang, 2020). Some Islamic groups see that the government is not serious about managing the economy, so that poverty has decreased, that is, it has reduced to their grandchildren. Besides, the government's repressive attitude towards Muslims, such as data collection on lecturers, setting mosque loudspeakers, the number of violent cases against Islamic leaders that are not revealed, naturally leads to religious sentiment and amplifies propaganda from one group to another (Fitriani, Satria, Nirmalasari, \& Adriana, 2018, pp. 1-18).

The essence of the media used by propaganda is to invite all citizens in Yogyakarta to fight against deviations from the Islamic religion, mainly Shi'a. For some Islamic groups, Shi'a teachings are far from Islam's teachings. Such as mut'ah marriage, matters of faith, a celebration of Ashura, etc., (Hastuti \& Maulana, 2019, pp. 31-40). In the tabligh akbar, for instance the Shi'a Free Yogyakarta Declaration, it is stated that Yogyakarta residents expelled immigrants from Afghanistan who embraced Shi'a in Manggung, Caturtunggal, Sleman. According to the community, the teaching was very unsettling for the community. The people in Yogyakarta put up several banners to make people aware of the Shi'a movement in Indonesia, which is considered troubling for the people. Its means that there is a significant potential for conflict between the adherents of Sunni and Shi'a ideology in Indonesia. (Zatullah, 2021, pp. 86-101).

The forms of media used to carry out anti-Shi'a Propaganda in Yogyakarta are billboards, banners, leaflets, brochures. Some are installed on the side of the road, and some are installed near the mosque. Meanwhile, online distribution via social media such as Facebook and WhatsApp groups. 
The propaganda publication media's influence on the audience is enormous because, in a relatively short time, the audience who saw the image would think and wonder what Shi'a is. The picture (media) influences the audience to be active and take the initiative to find out what Shi'a is. The impact on a person depends on several things, including the characteristics of a person's personality and various aspects of the situation and context. Of course, it will cause changes in each audience's knowledge, attitudes, and behavior. The most significant influence of this image is that most Sunnis will better understand the meaning of this image and take steps not to be influenced by the Shi'a. However, it is also possible to swallow that information blindly and justify the Shi'a as heretical.

The act of propaganda by attaching various provocative attributes and tending to blame different groups is certainly small ripples of intolerance (Makhsum, 2019). The problem of discrimination is caused by the level of public awareness in Yogyakarta. Yet, sometimes, it is triggered by the government's attitude in making policies that trigger radicalism, such as the attitude of the Rector of UIN Sunan Kalijaga, who tends to suspect women who wear the hijab. Even though the policy was canceled due to a polemic, it was already widespread in society. Wearing the hijab a human right, is not it? People wearing the hijab certainly cannot always be considered radicals or terrorists.

Brian J. Grim and Roger Finke made three indicators to measure tolerance: the privilege of government in minority groups, social regulations, and policies of the central government or local government. The emergence of propaganda media posted in Yogyakarta shows that these three things are not working optimally. The provincial government does not immediately revoke or demote the press, even though local laws or regulations exist. On the other hand, the people let them. So much of the anti-Shi'a propaganda media has been attached and installed for months (Setarainstitute, 2017). The categories of propaganda technique used can be classified as follows:

\section{Name-Calling}

It is done by touching emotional symbols to a person, group, or country. The goal is an immediate, heartfelt response without resistance. In this technique, a stereotype about the target is generated. Like the media below:

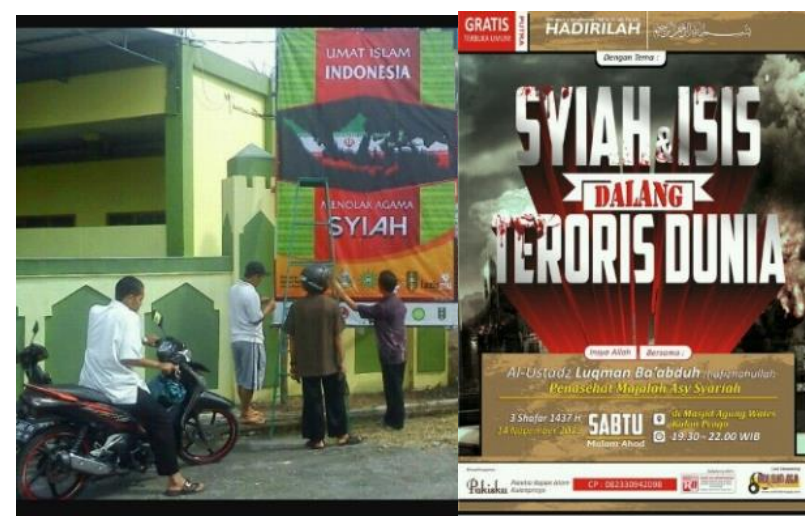

(a) (b)

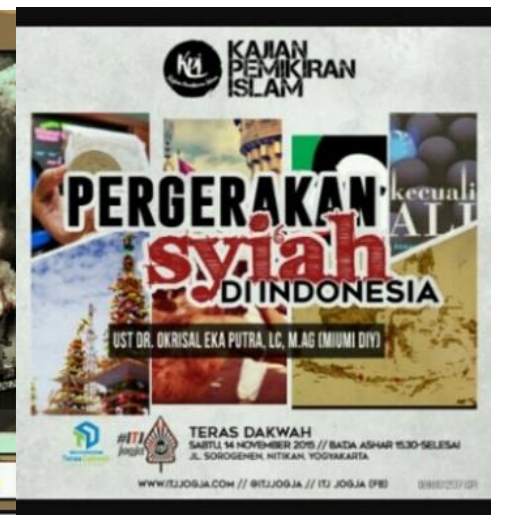

(c)

Figure 3. (a) Installation of anti-Shi'a propaganda billboards in front of places of worship, (b) Anti-Shi'a propaganda flyer image, (c) Image of the anti-Shi'a propaganda leaflet 


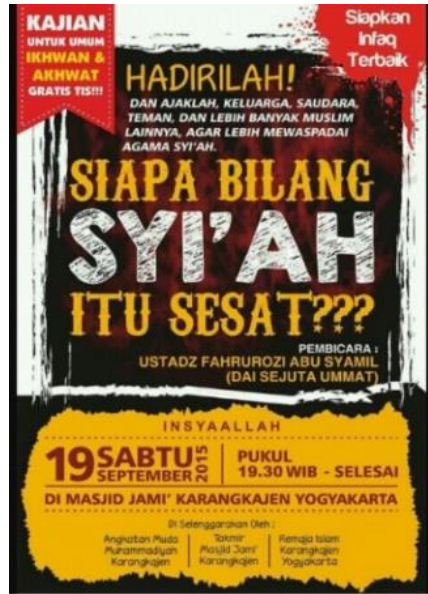

(a)

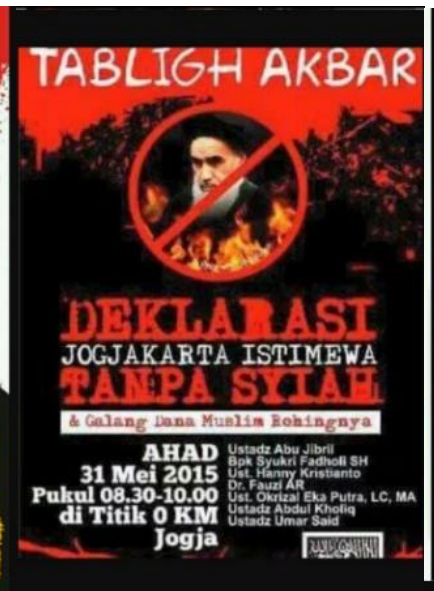

(b)

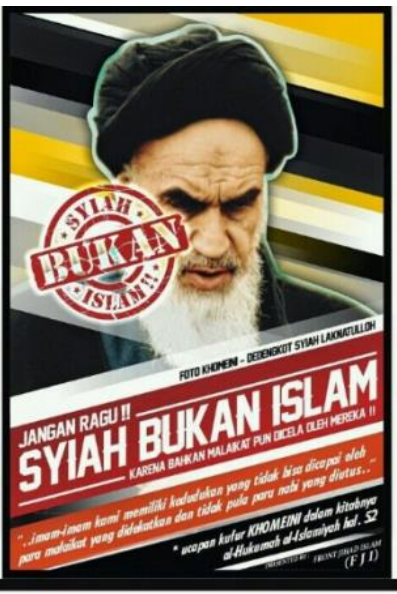

(c)

Figure 4. (a) anti-Shi'a propaganda flyers circulating on the internet, (b) anti-Shi'a propaganda flyers circulating on the internet, (c) anti-Shi'a propaganda flyers circulating on the internet

Terrorists and radical groups always need the media to carry out agitation and propaganda and shape public opinion (Junaedi, 2017, pp. 15-25). Banner images like the one above also affect audiences who know and read them and understand the message's purpose. This impact can make someone strengthen their argument, who initially understood that Shi'a had deviated from the true religion of Islam. A more significant impact can also be an audience to influence others to co-create an action. The action here is like an oration, demonstration, or action proclaiming that Shi'ism has deviated from the teachings of Islam. These actions were all an impact of the media (banners) conveying information that Shi'a is not Islam. From these writings, it is clear that the Shi'a are heretical. The audience will perceive that Shi'a teachings are not good, sinful. The message written in this image can be immediately understood by the audience who see and read it. The function of this image is to commemorate the Shi'a teachings that have emerged in Indonesia to be aware of these teachings, as an appeal to those who see and read this picture that Shi'a teachings are heretical.

Campaigning anti-Shi'a using the media is the same as providing information to the audience, so it would be nice if the story has a clear foundation and grip. Likewise, when campaigning anti-Shi'a, it should explain why Shi'a are deviant and why Shi'a should not be followed. Those reasons must be clear and solid. This image is very influential because, with this image, the community will understand more about Shi'a, be more aware of the understanding that goes into it. If there is no image, maybe the community will feel more relaxed and do not know Shi'a. Of course, for pro, the existence of this anti-Shi'a movement will have a considerable influence. They could be passive in expressing their opinion about Shi'a's disagreements, so having this image will make it active. Moreover, propaganda like the one above is used as legitimacy to commit intolerant acts (Makin, 2017, pp. 1-32).

The propaganda media above touches emotionally because it was first installed in front of the mosque. Mosques are holy places for worship. There are two things the emotional side is touched on. Those who disagree will certainly feel sad because the mosque that should be used to spread peace is used to spread hatred. Meanwhile, those who agree to propaganda will feel their views have legitimacy in a holy place. Besides that, the use of the words that "Shia is the same as ISIS and is a terrorist movement" is undoubtedly a statement that is no joke. Terrorism is a crime in religious institutions and in Indonesian state institutions; one can be arrested for imprisonment. Propaganda by anti-Shia groups carried out by the word terrorist equating the Shia group and using mosques to spread propaganda is a means of touching people's feelings in seeking legitimacy (Junaedi, 2017, pp. 15-25).

\section{Glittering Generality}

If the first technique touches with symbols, then this technique uses grandiose words. It is done to trick the public so that they are lulled. Some of the media of this technique are displayed below: 


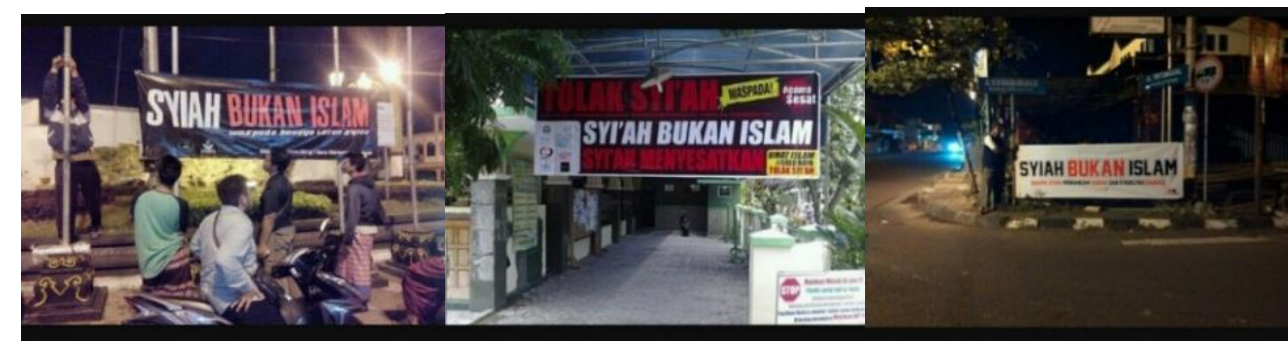

(a)

(b)

(c)

Figure 5. (a) An anti-Shi'a propaganda banner by the side of the road, (b) Anti-Shi'a propaganda banners crossed the road, (c) An anti-Shi'a propaganda banner by the side of the road

The pictures aim as justification that the Shi'a can be confirmed as heretical. It is an easy propaganda method. Sufficiently spreading as much media as possible is done to achieve the target, creating public opinion. The picture conveys a meaning to the audience that Shi'a is a school that must be avoided because it contradicts Islamic teachings. Shi'a ideology is inideology (Ali Muhtarom, 2017, pp. 73-95). The images made in banners placed in crowded places are extensively produced so that people can see and read so that the audience will be influenced and even curious about the Shi'a and why it should be avoided.

Indeed, the acts of extremism were carried out by some provocateurs in society and indeed had affiliations with radical groups (Luqyana \& Sukmono, 2020, pp. 77-87). In Nurudin's view, the word used in this technique is grandiose sentences as justification. Like the word "Shia is not Islam" or "Shia is misleading" (Nurudin, 2001). The anti-Shia groups laud themselves as if they are the truest to their faith, do not have a deviant religion, and feel that they are the most authentic Islam. They conveyed to the public that people must avoid Shia teachings if they want to be straight and true Islam (Zakiyuddin, 2018, pp. 39-57). The communicator raises the issue that Shi'a is not Islam and is misleading. Therefore, the communicator wanted to invite an individual not to adhere to Shi'ism as if it were an invitation to imbue the individual reading it. The issues discussed are susceptible so that the audience can follow or comment on the subject. Nevertheless, there are always pros and cons because each individual must have their own beliefs and arguments.

\section{Transfer}

This technique usually uses a person's popularity to rely on as an excuse that the figure is part of his group if he benefits from public opinion. Still, if it is not profitable, then it is not considered the group. Like the media below:

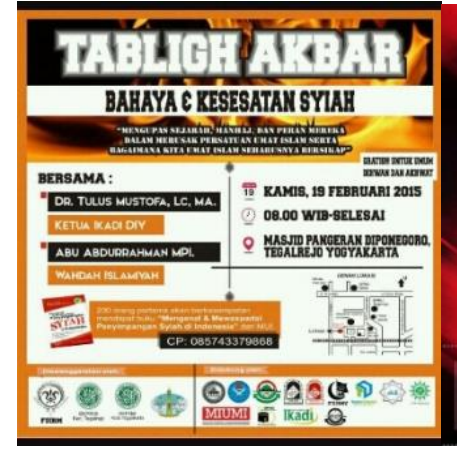

(a)

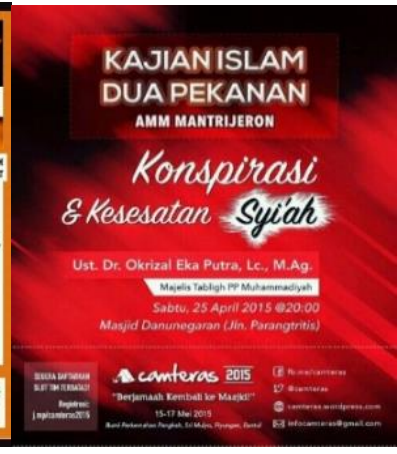

(b)

Figure 6. (a) anti-Shi' a propaganda billboards, (b) anti-Shi'a propaganda brochures

In the media displayed above, it seems as if the propagandists want to make the Shi'a important information and study material for the community. Even the press emphasizes the issues which are considered essential and sometimes underestimated information that the public may need. In places such as mosques, billboards were posted about rejecting Shi'a teachings. The crowd was kept informed with brochures related to Shi'a. The purpose of the image is to invite the audience (the public) to share their content with the billboard's message. On the billboard, it was clear that he rejected Shi'a teachings. Indirectly, the contents of the statement given by the billboard were invited 
to unite in blocking and rejecting the spread of the Shi'a sect. In the picture above, there is a billboard placed next to the mosque. It is so that people who generally come to the mosque to worship can see the billboards. It is hoped that this installation can make people aware when influenced by Shi'a teachings.

Propaganda publication in the picture above brought AMM or the Muhammadiyah Young Association as the organizer. Even the logos of the Muhammadiyah organization were also covered. It can be ascertained that this was the act of people who used Muhammadiyah as legitimacy. Officially, Muhammadiyah does not question the existence of the Shia group. Even Muhammadiyah tends to protect and cooperate with other minority groups (Khittah.co, 2017). It can be ensured that the name of the organization or institution is written down because there is no official statement from Muhammadiyah institutions regarding this matter. The general secretary of Muhammadiyah had claimed this is fraud.

Both puritan and traditionalist groups represent the rejection of Shi'a in Indonesia. Like Al Irshad, PERSIS, and NU. Meanwhile, modern, moderate groups such as Muhammadiyah and parts of NU may be more tolerant (Ali Muhtarom, 2017, pp. 73-95). Other Puritan groups that are considered to tend to act intolerantly are HTI and FPI. HTI is well known for its political movements that are promoted by changing the state ideology of Pancasila with the Khilafah. Meanwhile, FPI is known for its move to dismiss events deemed immoral, like raiding discotheques and closing food stalls that are open during the month of Ramadan. Meanwhile, from NU circles, the intolerance movement is at the grassroots, as explained by Marcus Mietzner and Burhanuddin Muhtadi (Marcus Mietzner and Muhtadi, 2020, pp. 58-83). Other cases involving acts of intolerance by NU were the Shia conflict in Sampang Madura (Viva.co.id, 2011), prohibition of non-Muslim residents from living in Bantul, Yogyakarta, (Syambudi, 2019), rejection toward Ustadz Abdul Shomad in Jepara and Ustadz Khalid Basalamah, prohibition of the establishment of Muhammadiyah mosques in Bireun, Aceh (Rostanti, 2016), and the cancellation of Muhammadiyah cycle event in Jepara.

Religion is to teach peace, but due to the influence of ideology, political views, and the interests of some elites in society, the understanding of religion can turn into intriguing action (Zatullah, 2021, pp. 86-101), such as the attitude to the Shi'a adherents.

\section{CONCLUSION}

Propaganda is carried out using media such as billboards, posters, leaflets, banners. This media is distributed online and offline. Offline media installed in various strategic places such as mosques, road junctions, and other public places. Online propaganda media is distributed on websites and social media. The propaganda process carried out includes Name-calling, Transfer, glittering Generality. This propaganda provided a stimulus to the audience or the public to seek knowledge and information about the Shi'a group. The media's propaganda work mechanism provides information to the general public by placing the media in strategic places. The press only provides information effectively to the few who see it.

This research suggests, first, the public to be alert and not easily provoked by various propagandarelated information because the information is not accurate and can be justified. Second, the government already has all the tools to curb various media with provocative tones and propaganda that incites hatred towards other groups. Supposedly, if there are such media that appear, the officials must immediately deny it and investigate it. Third, further research is necessary to know the effectiveness of anti-Shia propaganda in Yogyakarta. It is essential to measure the quantity of action or movement and intolerance. Also, it is necessary to look at the overall relationship with other variables such as economics or politics. It is necessary because the act of spreading the banner is usually closely related to political momentum. It needs to be revealed whether other people take advantage of certain groups or deliberately use Yogyakarta to spread hatred to other groups to divert other vital issues. 


\section{REFERENCES}

Ahyar, D. B. (2019). Analisis Teks Dalam Penelitian Kebahasaan. Shaut Al-'Arabiyah, 7(2), 100-120. https://doi.org/10.24252/saa.v7i2.10273

Ali Muhtarom. (2017). the Study of Indonesian Moslem Responses on Salafy- Shia Transnational Islamic Education Institution. Jurnal Ilmiah Islam Futura, 17(1), 73-95.

An-nahidl, N. A. (2014). Ijabi dan Pendidikan Ahlul Bait: Studi Kasus Pada Yayasan Muthahhari Bandung. 12(06), 114-132.

Anshori, A. B., Nurhasanah, S., \& Napang, M. (2020). the Threat of Economic Recession and Its Impact on Global Terrorism. Journal of Terrorism Studies, 2(1), 210. https://doi.org/10.7454/jts.v2i1.1014

Assiddiqie, J. (2014). Makalah disampaikan dalam Dialog Kebangsaan dengan tema "Toleransi Beragama”, . Jakarta.

Azra, A. (2015a). Proxy War (1). Retrieved January 3, 2021, from republika.co.id website: http://www.republika.co.id/berita/kolom/resonansi/15/08/12/nsz4pi319-proxy-war-1

Azra, A. (2015b). Proxy War (2). Retrieved January 12, 2021, from republika.co.id website: http://www.republika.co.id/berita/kolom/resonansi/15/08/19/ntbxsu319-proxy-war-2.

Creswell, J. W. (2012). Research Design : Pendekatan Kualitatif, Kuantitatif dan Mixed. Yogyakarta: Pustaka Pelajar.

Eriyanto. (2002). Analisis Framing. Konstruksi Ideologi dan Politik Media. Yogyakarta: Lkis Pelangi Akasara.

Fitriani, Satria, A., Nirmalasari, P. P., \& Adriana, R. (2018). The Current State of Terrorism in Indonesia - Vulnerable Groups, Networks, and Responses. In Centre for Strategic and International Studies. Retrieved from https://www.csis.or.id/publications/the-current-stateof-terrorism-in-indonesia-vulnerable-groups-networks-and-responses

Gerintya, S. (2018). Benarkah Intoleransi Antar-Umat Beragama Meningkat? Retrieved January 20, 2020, from tirto.id website: https://tirto.id/benarkah-intoleransi-antar-umat-beragamameningkat-cEPz

Hastuti and Maulana, H. F. (2019). Konflik Ideologi Syiah Dan Sunni Dalam Media Online. MEDIALOG: Jurnal Ilmu Komunikasi, 2(1), 31-40. Retrieved from http://jurnalumbuton.ac.id/index.php/Medialog/article/view/152

Hitti, P. (2008). History of The Arabs. Jakarta: Serambi.

Junaedi, F. (2017). Relasi Terorisme dan Media. Jurnal ASPIKOM, 1(1), 15-25. https://doi.org/10.24329/aspikom.v1i1.5

Khittah.co. (2017). Sekum PP Muhammadiyah: Muhammadiyah Tidak Pernah Membuat Penyataan Syiah Adalah Aliran dan Paham Sesat. Retrieved April 23, 2021, from khittah.co website: http://www.khittah.co/sekum-pp-muhammadiyah-muhammadiyah-tidak-pernah-membuatpenyataan-syiah-adalah-aliran-dan-paham-sesat/8723/

Latief, H. (2008). The Identity Of Shi 'a Sympathisers In Contemporary Indonesia. Journal of Indonesian Islam, 02(02), 300-335.

Lee, A. . and E. B. L. (1939). The Fine Art of Propaganda: A Study of Father Coughlin's Speeces. New York: Harcout, Brace and Company.

Luqyana, Y. D., \& Sukmono, F. G. (2020). Isu Intoleran dan Video Akun Menjadi Manusia (Sebuah Pendekatan Penerimaan Penonton). Jurnal Audiens, 1(1), 77-87. https://doi.org/10.18196/ja.11010

Makhsum, A. (2019). Stigmatisasi Dan Propaganda Anti-Syiah: Sorotan Deskriptif Gerakan Annas. Jurnal CMES, 12(2), 182-191. https://doi.org/10.20961/cmes.12.2.37894

Makin, A. (2017). Homogenizing Indonesian Islam: Persecution of the Shia group in Yogyakarta. Studia Islamika, 24(1), 1-32. https://doi.org/10.15408/sdi.v24i1.3354

Marcus Mietzner and Muhtadi, B. (2020). The Myth of Pluralism : Nahdlatul Ulama and the Politics of Religious The Myth of Pluralism: Nahdlatul Ulama and the Politics of Religious Tolerance in Indonesia. Contemporary Southeast Asia, 42(1), 58-83. https://doi.org/10.1355/cs42-1c

Mc Nair, B. (1999). An Introduction to Political Communication (2nd editio). London: Routledge.

McQuail, D. (1994). Teori Komunikasi Massa : Suatu Pengantar. Jakarta: Erlangga.

Moleong, L. J. (2017). Metodologi Penelitian Kualitatif. Edisi Revisi. Bandung: Remaja Rosda Karya.

Nurudin. (2001). Komunikasi Propaganda. Bandung: Remaja Rosda Karya. 
Rahmat, J. (2001). Metode Penelitian Komunikasi. Bandung: Remaja Rosda Karya.

Rostanti, Q. (2016). Ini Kronologi Larangan Pembangunan Masjid Muhammadiyah di Aceh. Retrieved April 20, 2021, from republika.co.id website: https://republika.co.id/berita/duniaislam/islam-nusantara/16/06/09/o8he68361-ini-kronologi-larangan-pembangunan-masjidmuhammadiyah-di-aceh

Salim, A. (2006). Teori dan Paradigma Penelitian Sosial. Yogyakarta: Tiara Wacana.

Setarainstitute. (2017). Indeks Kota Toleran Tahun 2017. Retrieved January 4, 2021, from setarainstitute.org website: https://setara-institute.org/indeks-kota-toleran-tahun-2017/

Subhani, J. (2012). Syi'ah: Ajaran dan Praktiknya. Jakarta: Nur Al-Huda.

Syambudi, I. (2019). Non-Muslim Dilarang Bermukim, Aturan Janggal di Dukuh Karet Bantul. Retrieved April 20, 2021, from tirto.id website: https://tirto.id/non-muslim-dilarangbermukim-aturan-janggal-di-dukuh-karet-bantul-dkVH

Tempo.com. (2012). Bagaimana Kronologi Syiah Masuk Sampang? Retrieved January 5, 2020, from tempo.com website: https://nasional.tempo.co/read/426989/bagaimana-kronologi-syiahmasuk-sampang

Viva.co.id. (2011). Penyerangan ke Syiah Sudah Terjadi Sejak Lama. Retrieved January 4, 2021, from Viva.co.id website: https://www.viva.co.id/berita/nasional/276312-penyerangan-kesyiah-sudah-terjadi-sejak-lama

Wijayanti, Y. T. (2020). Radicalism Prevention through Propaganda Awareness on Social Media. Jurnal ASPIKOM, 5(1), 142-155. https://doi.org/10.24329/aspikom.v5i1.501

Zakiyuddin, A. (2018). Teknik Teknik Propaganda Politik Jalaludin Rahmat (Sudy Kasus pada Kampanye Pemilu 2014 di Kabupaten Bandung dan Bandung Barat). Jurnal Academia Praja, 1(1), 39-57.

Zatullah, N. (2021). Konflik Sunni-Syiah di Sampang Ditinjau Dari Teori Segitiga Konflik Johan Galtung. Jurnal Ilmu Budaya, 9(1), 86-101. 